\title{
An Investigation into Undergraduates' Errors in the use of the Indefinite Article at Omar Al-Mukhtar University
}

\author{
Ahmed Gaibani \\ Department of English Language, Faculty of Arts and Sciences, Omar Al-Mukhtar University, Libya \\ E-mail: dr.ahmed.Gaibani@gmail.com
}

Doi:10.7575/aiac.alls.v.6n.6p.195

URL: http://dx.doi.org/10.7575/aiac.alls.v.6n.6p.195
Received: 08/08/2015

Accepted: 12/10/2015

\begin{abstract}
The purpose of this study was to examine the use of English articles as well the errors made by the students at Omar AlMukhtar University. The research objectives consists of : To identify the types and sources of errors made by Libyan EFL Undergraduates at Omar Al-Mukhtar University in the use of the indefinite article during their written composition, To determine the major types of errors in which larger numbers of errors have been committed by the students in their written composition. Based on previous studies, a qualitative method of data collection represented by an essay-writing composition is implemented in this study. Moreover, they were asked to write essay writing composition of the following topics "Discuss The Problems You Face In Learning English Language?" The results provide of this study, reporting the information collected from Compositions and analyzed by using descriptive statistical percentages in terms of errors numbers and percentages of errors occurrences under their major types, which enabled the researchers to put these in an order of their occurrences. In other words, data were organized using categories given to each of these errors. Regarding the length of compositions, a total of (2194) English words were written by the students across their university levels. Freshmen wrote a total of (1193) words which represents (54.37\%) whereas sophomores wrote (1001) words which represents $(40.62 \%)$. These research also suggest that there is a significant and negative impact of the use of English Articles. Since majority of students agreed that the English Articles are important, and we should look at the importance of English language as well as how students improve their proficiency in English articles towards mastering the use of English language.
\end{abstract}

Keywords: Writing, English language, Articles, Morpheme, communication, Language Acquisition, Grammar

\section{Introduction and Background}

The English article system is said to be considered one of the most difficult structural elements for ESL/EFL learners, especially for those whose mother tongues do not employ articles or article-like morphemes. The idea is strongly emphasized by different researchers such as Master (2002) who attributes the difficulty of using the indefinite articles to three facts: (a) Articles are among the most frequent function words in English (Celce-Murcia and Larsen-Freeman, 1999), which make constant rule application difficult over an extended stretch of discourse; (b) normally, function words are unstressed and thus, they are difficult for non-native speakers to recognize, which consequently affects the available input in the spoken form; and (c) the article system has multiple functions onto a single morpheme, which constitutes a considerable burden for the learners who often look for a one-to-one correspondence between form and function, especially in the case of the early stages of language learning (Master, 2002). Although articles are generally unstressed, they are considered as hardly crucial communication devices; this gives the reason why they are dropped in telegraphic exchanges (Bataineh, 2005). Moreover, articles are said to be acquired at late stages of learning as it has been pinpointed by Brown (1973) when he discovered that the acquisition of articles came number 9 in the acquisition process of fourteen morphemes; after the acquisition of morphemes like prepositions in and on, regular plural and possessive inflection $-\mathbf{s}$, and before morphemes like the present progressive inflection -ing, regular and irregular third person singular (e.g. cleans and has), regular and irregular past tense (cleaned and went) and contracted and un contracted copula and auxiliary be (Brown, 1973). Accordingly, the difficulty of the acquisition as well as the use of articles makes students commit article errors, and thus, this leads to plague the students' speech and writing. Interestingly, in the case of Arab world, Arab students are facing many problems while they are speaking and writing English as a foreign or a second language. Regarding the case of Libya, much research has been conduced to address language problems, especially those in writing (Rababah, 2003; Zugoul, 1984; and Abdul Haq, 1982). For example, it has been stated by Abdul Haq (1982:1) that "One of the linguistic areas in which students in the secondary cycle commit errors is in the writing skill". He adds "There are general outcries about the continuous deterioration of the standards of English proficiency of students among school teachers, university instructors and all who are concerned with English language teaching". Within the same context, Libyan EFL students commit serious lexical errors while communicating in English. 
English article system represented by a, an, zero, and the, are from the functional structures that are quite difficult for non-native English speaking learners, and even for those who are learning English as their first language. Additionally, the definiteness errors are considered the most frequent problems that face EFL learners especially Arab learners as their written communication (i.e. compositions) were heavily affected by these kinds of errors (Willcott, 1972). Moreover, articles are believed to be a source of difficulty for learners (and teachers) of English as a second/foreign language, especially for those whose native languages do not have articles or do have articles or article-like morphemes but are used in different ways from those in English (Celce-Murcia and Larsen-Freeman, 1999). Libya as one of the countries in which English is taught as a foreign language, undergoes this difficulty through its EFL university students' errors in the use of articles, clearly because the system of definiteness and indefiniteness in both languages Arabic and English, is acquired differently. Based on, Bataineh (2005) and Zughoul (2002) Jordanian Learners, face a difficulty in the use of English articles during their speeches and writings. It has been emphasized that Libyan students like other EFL students the problem is greater when those students are exposed to write an essay or a paragraph, they commit serious problems in the use of articles, especially the indefinite articles a, an, and zero article.

\subsection{Research Objectives}

1. To identify the types and sources of errors made by Libyan EFL Learners at Omar Al-Mukhtar University in the use of the indefinite article during their written composition.

2. To determine the major types of errors in which larger numbers of errors have been committed by the students in their written composition.

\section{Literature Review}

Much research has been conducted to address learners' misuse or errors in using articles in EFL/ ESL contexts in general, and in the Arab world in particular. In this respect, Lyons (1999) claims that although the system of both languages Arabic and English is, to some extent, similar in the use of articles (i.e. definite and indefinite articles), EFL university students have many difficulties and committed errors in the use of definite and indefinite articles in their written compositions. Lyons (1999) here shows how the system of both languages works with regard to articles, that is, there are two types of articles in Arabic, the definite article which is marked by the prefix /al/ and the indefinite which is always marked by the absence of the prefix /al/, whereas English on the other hand, has two types, the definite marked by /the/ and the indefinite marked by a(n) ) and zero (Lyons, 1999). A plethora of research has been carried out addressing the difficulties that EFL learners face while learning English as a foreign language as a result of the clash found between two systems of languages their native languages (Source Language (SL)) and the target language, henceforth English. In the case of the difficulties in articles, Master (1987) attributes such difficulties that our EFL students suffer from to their native language. In other words, Master (1987) refers here that the major source of the problem is the differences between languages in their article systems; such kinds of learners always use zero articles, especially at the beginning stages. Moreover, the learners' background knowledge of the target language is said to play a key role as a source of some linguistic problems in most EFL/ ESL contexts. Bataineh (2005) asserts that the more limited background knowledge of English, the more serious problems the learner commits (Bataineh 2005). Besides, it has been claimed that the first study which has addressed the acquisition of articles is Master's (1987) in which he points out that articles are acquired differently based on their occurrence or non-occurrence in the learners' native language. Additionally, some studies have addressed the precedence of article acquisition such as (Huebner, 1983; Master, 1997; Parrish, 1987 and Thomas, 1989) in which it is suggested that the definite article the is acquired before the indefinite article $\boldsymbol{a}$, while other studies have found that the definite article is overused (Huebner, 1985; Parrish, 1987; Thomas, 1989; Chaudron and Parker, 1990).

Specifically, in the case of articles usage in EFL/ ESL contexts, there is an apparent need to be taught because they carry meaning and using them erroneously usually causes confusion and misreading (Rinnert and Hansen, 1986 and Wrase, 1982). Furthermore, in an interesting study by Rinnert and Hansen (1986) in which both researchers make one thousand learners from different language backgrounds follow a systematic instructional approach in which a selfdeveloped material is used, it has been reported how observable the learners' improvement in articles usage and very few textbooks taught in EFL/ ESL contexts present a systematic approach or adequate practice in order to affect positively the learners' performance in the use of articles (Rinnert and Hansen (1986). What is being highlighted here from Rinnert and Hansen's (1986) study is that EFL/ ESL teachers have to find other resources or self-developed materials to teach articles rather than to rely only on the textbooks which to some extent do not present a thick or intensive material in which the learners get involved to interact with the whole classroom to learn and master their usage and thus overcome erroneous situations (i.e. compositions, speeches, etc).

In a study conducted by Zughoul (2002) on 25 US university Arab students from different Arab countries (Algeria 2, Libya 5 ,Egypt 5,Jordan 3,suadi Arabia 7,Bahrain 1) who were attending an intensive English program in the University of Texas, the findings indicate that the articles errors dominate the most frequent in noun phrases with (47.2\%) represents the omission of the indefinite articles a(n) from the noun phrase errors, and (44.6\%) represents the omission of $\mathrm{a}(\mathrm{n})$ in contexts where their use is obligatory. He ascribes these frustrated results to the differences in the definiteness and indefiniteness systems in both languages Arabic and English, that is, Arabic has no equivalent to (a or an ) in English and thus errors are said to occur (Zughoul, 2002). What has been emphasized here is the fact that although both Arabic and English have the same definiteness and indefiniteness systems (i.e. the Arabic defined form is marked by 
/al/ which corresponds to /the/ in English, and the Arabic undefined form is marked by the absence of /the/ which corresponds to the use of (/a/, /an/ and zero), indefiniteness in English is marked by lexical items such as /the/ and /a/ while it is marked in Arabic by affixes such as the prefix /al/ and the suffix $-\mathbf{n}$, both to mark definiteness and indefiniteness respectively (Lyons, 1999)

\section{Methodology}

A total of 15 Libyan EFL non-English majoring undergraduate students who are enrolled in the first semester of the academic year 2013/2014, at Omar Al-Mukhtar University and whose ages were between 23-28, were selected as the sample of this study. The subjects started their degree in 2011, 2012, respectively, which made them of two groups freshmen (consisted of 9 students) and sophomores (consisted of 6 students) at the time of the research (see table 1).

Table 1. Distribution of the subjects according to their numbers and percentages

\begin{tabular}{lll}
\hline University Year & Number & Percentage \\
\hline Freshmen & 9 & $60 \%$ \\
\hline Sophomores & 6 & $40 \%$ \\
\hline
\end{tabular}

Additionally, the subjects were non-English majors and were taken from different schools: School of Education, Law, Engineering, and Mathematics (see table 2). The students were non-English majors clearly because during their speech and writing, they do not pay very much attention to the simple grammatical errors exemplified by the use of articles rather they are focusing on communication.

Table 2. Distribution of students according to their university year and areas of specialty

\begin{tabular}{lllll}
\hline Scho/Area of specialty & Freshmen & Sophomores & Total & Percentage \\
\hline Education & 2 & 1 & 3 & $20 \%$ \\
\hline Law & 1 & 2 & 3 & $20 \%$ \\
\hline Engineering & 4 & 2 & 6 & $40 \%$ \\
\hline Mathematics & 2 & 1 & 3 & $20 \%$ \\
\hline Total & 9 & 6 & 15 & $100 \%$ \\
\hline
\end{tabular}

\subsection{Material and Procedures}

A qualitative method of data collection represented by an essay-writing composition is implemented in this study. Moreover, they were asked to write essay writing composition of the following topics "Discuss The Problems You Face In Learning English Language?"

\subsection{Data Analysis Technique}

After the compositions have been collected, each one of them was read carefully by the researcher. Then, data from each reading were interpreted, analyzed using descriptive statistical percentages in terms of errors numbers and percentages of errors occurrences under their major types, which enabled the researchers to put these in an order of their occurrences. In other words, data were organized using categories given to each of these errors. Regarding the length of compositions, a total of (2194) English words were written by the students across their university levels. Freshmen wrote a total of (1193) words which represents $(54.37 \%)$ whereas sophomores wrote (1001) words which represents (40.62\%). (See tables3 and 4).

Table 3. total of written words based on University level and Student school

\begin{tabular}{|c|c|c|c|c|c|c|}
\hline \multirow{3}{*}{$\begin{array}{l}\text { Student's } \\
\text { Major }\end{array}$} & \multicolumn{4}{|c|}{ Number of written words per Uni/Year } & \multirow{3}{*}{$\begin{array}{l}\text { Total number of } \\
\text { words }\end{array}$} & \multirow{3}{*}{$\begin{array}{l}\text { Percentage } \\
\text { of all Errors }\end{array}$} \\
\hline & \multicolumn{2}{|l|}{ First } & \multicolumn{2}{|l|}{ Second } & & \\
\hline & Stud. No & words No. & Stud No. & words No. & & \\
\hline Education & 2 & 224 & 1 & 134 & 358 & $16.31 \%$ \\
\hline Law & 1 & 152 & 2 & 264 & 416 & $18.96 \%$ \\
\hline \multicolumn{7}{|l|}{ Engineering } \\
\hline & 4 & 545 & 2 & 375 & 920 & $41.93 \%$ \\
\hline Mathematics & 2 & 272 & 1 & 228 & 500 & $22.78 \%$ \\
\hline
\end{tabular}




\begin{tabular}{|c|c|c|c|c|c|c|c|}
\hline \multirow{2}{*}{$\begin{array}{l}\text { Student's } \\
\text { Major }\end{array}$} & \multicolumn{4}{|c|}{ First-year Stud. number of words } & \multicolumn{3}{|c|}{$\begin{array}{l}\text { Second - year Stud. number of } \\
\text { words }\end{array}$} \\
\hline & Stud. 1 & Stud. 2 & Stud.3 & Stud.4 & Stud.1 & Stud. 4 & Total \\
\hline Education & 109 & 115 & --- & --- & 134 & --- & 358 \\
\hline Law & 152 & --- & --- & --- & 142 & 122 & 416 \\
\hline Engineering & 161 & 89 & 123 & 172 & 174 & 201 & 920 \\
\hline Mathematics & 154 & 118 & --- & --- & 228 & --- & 500 \\
\hline Total & 576 & 322 & 123 & 172 & 678 & 323 & 2194 \\
\hline $\begin{array}{l}(2194) \\
(100 \%)\end{array}$ & \multicolumn{4}{|c|}{$\begin{array}{l}\text { First-year total (1193) } \\
(54.37 \%)\end{array}$} & \multicolumn{3}{|c|}{ Second-year total (1001) (45.62\%) } \\
\hline
\end{tabular}

\section{Findings and Discussion}

This study addresses the research objectives to identify the types and sources of errors made by Libyan EFL Learners at Omar Al-Mukhtar University in the use of the indefinite article during their written composition as well as to determine the major types of errors in which larger numbers of errors have been committed by the students in their written composition. Relating to the role played by the use of indefinite article in influencing students' writing ability 15 students were examined through writing compositions. The students in their 15 written essays have made many errors grammatical or syntactic, but the researchers here have put much attention to the students' errors in the use of the indefinite articles because they are addressed to conduct this study. Significantly, through the analysis of the students' compositions, it has been found that the students made (112) article errors. Freshmen made (75) errors which represent (66.96\%), whereas sophomores made (37) errors which represent (33.03\%) from the total errors respectively (See table $5)$.

Table 5. Numbers of errors and percentages according to students' university level

\begin{tabular}{lll}
\hline University Year & Number of errors & Percentage \\
\hline Freshmen & 75 & $66.96 \%$ \\
\hline Sophomores & 37 & $33.03 \%$ \\
\hline
\end{tabular}

Identifying the types of errors as it has been handled by Bataineh (2005), these errors were computed and classified in terms of their errors numbers in nine categories across the students' university levels.

Table 6. Types of errors and their percentages across the university level

\begin{tabular}{|c|c|c|c|c|c|c|c|c|c|c|}
\hline $\begin{array}{c}\text { Errors } \\
\text { Uni. Levels }\end{array}$ & $\begin{array}{l}\text { Deletion } \\
\text { of the } \\
\text { indefinite } \\
\text { article }\end{array}$ & $\begin{array}{l}\text { Writing a } \\
\text { as part of } \\
\text { following } \\
\text { word }\end{array}$ & $\begin{array}{l}\text { Substituti } \\
\text { on of the } \\
\text { indefinite } \\
\text { for the } \\
\text { definite }\end{array}$ & $\begin{array}{l}\text { Substitution } \\
\text { of the } \\
\text { definite for } \\
\text { the } \\
\text { indefinite }\end{array}$ & $\begin{array}{l}\text { Substit } \\
\text { ution of } \\
\text { a for an }\end{array}$ & $\begin{array}{l}\text { Use of } \\
\text { indefini } \\
\text { te with } \\
\text { unmark } \\
\text { ed } \\
\text { plurals }\end{array}$ & $\begin{array}{l}\text { Use of } \\
\text { indefini } \\
\text { te with } \\
\text { marked } \\
\text { plurals }\end{array}$ & $\begin{array}{l}\text { Use of } \\
\text { indefinit } \\
\text { e with } \\
\text { uncoun. } \\
\text { nouns }\end{array}$ & $\begin{array}{l}\text { Use of } \\
\text { indefin } \\
\text { ite } \\
\text { with } \\
\text { adjs. }\end{array}$ & Total \\
\hline Freshmen & 23 & 2 & 9 & 16 & 1 & 8 & 7 & 7 & 2 & 75 \\
\hline Sophomores & 11 & 0 & 4 & 8 & 0 & 6 & 2 & 6 & 0 & 37 \\
\hline
\end{tabular}

\subsection{Types of errors}

With regard to the research questions what are the types and sources of errors made by Libyan EFL Learners at Omar Al-Mukhtar University in the use of the indefinite article during their written composition. What are the major types of errors in which larger numbers of errors have been committed by the students in their written composition? Results and findings shows that article errors has negative significant impact on the total of the use of indefinite articles the findings implies that students with lower skills or competence in English language are affected by committing errors in the use 
of English articles. The results of the current study suggest that non-English majoring undergraduate students at Omar Al-Mukhtar University commit errors on the use of English articles.

The following section presents the analysis of data across the following types of errors:

\subsubsection{Deletion of the indefinite article}

As mentioned in table 6, the deletion category is found as the major type in which most students across the two university levels commit large numbers of errors. In this category, both freshmen and sophomores made a total of (34) errors which represent $(30.35 \%)$ of the total number of errors distributed among them as $(20.53 \% 0)$ for freshmen with (23) errors and (9.82\%) for sophomores with (11) errors. Such deletion errors can be attributed to different sources from which the effect of students' native language (i.e. negative language transfer from Arabic) is found as the major source.

\subsubsection{Writing "a" is a part of the following word}

This type of articles errors seems to be the easiest to explain because it is in this study may not be ascribed to either the native or the target language. Rather it can be traced to transfer of training in the early acquisition processes. The errors of this category are very few in numbers committed all by freshmen with 2 errors represent $(1.78 \%)$ of the total errors. In this case, the indefinite article $\boldsymbol{a}$ was written in an inseparable form from the word following it.

\subsubsection{Substitution errors}

In this category, three types of substitution are found to occur in this study, substitution of the indefinite articles $\boldsymbol{a} / \boldsymbol{a n}$ or zero for the definite the, substitution of the definite the for the indefinite a/an or zero, and substitution of the indefinite $\boldsymbol{a}$ for $\boldsymbol{a n}$. In the first kind of substitution, both groups of the students commit (13) errors (11.60\%) in which they substitute a/an or zero for the. Freshmen committed a large number of errors (9) which represents (69.23\%) of the total errors of this category, whereas sophomores committed (4) errors which represent (30.76\%). These percentages indicate that freshmen group committed the majority of errors of this category than that of sophomores who committed less errors which may be as a result of their knowledge of target language. Additionally, the second kind of substitution seems to be the most frequent of other kinds of substitutions as both groups of students scored high number of errors (24) errors (21.42\%) of the total (112). Freshmen scored (66.66\%) of this kind of errors substitution with (16) errors, whereas sophomores scored (33.33\%) with (8) errors. Significantly, this kind of substitution is considered the second largest category in which both group of students erroneously substituted the for a/an and zero with (24) errors. The last kind of substitution (substitution of $\boldsymbol{a}$ for $\boldsymbol{a n}$ ) was the least in errors numbers, in which just one error is committed by the freshmen group. This indicates that most students have a knowledge of the target language by which they can differentiate between the usage of both indefinite articles $\boldsymbol{a}$ and $\boldsymbol{a n}$. In other words, this error may be due to a nonce mistake or a slip of the pen.

4.1.4 The use of the indefinite articles with unmarked plurals

In this category, both groups of students made a nearly close number of errors (14) represents (12.5\%) of the total number of errors distributed among freshmen with (8) (57.14\%) errors and sophomores with (6) (42.85\%). The number of errors made in this category seems to be closer in number indicating that both groups of students have a difficulty in the usage of the indefinite articles with unmarked plurals

4.1.5 The use of the indefinite articles with marked plurals

Unfortunately, both groups of the students made errors in this category when they erroneously used the indefinite articles a/an with those marked plural nouns making (9) errors representing (8.03\%) of the total errors, but sophomores in this category were less in committing such errors than freshmen who made the majority of errors with (7) errors $(77.77 \%)$ from the total errors of this category leaving (2) errors (22.22\%) for students of the second group (sophomores).

\section{1. 6. The use of indefinite articles with uncountable nouns}

Also it seems obvious from the results in table 6 that both groups of students are close in terms of the errors committed using the indefinite articles $\boldsymbol{a} / \mathbf{a n}$ with uncountable nouns. a total of (13) errors representing (11.60\%) ) from the total errors distributed among freshmen (7) errors with a percentage (53.84\%) and sophomores (6) errors with a percentage $(46.15 \%)$, respectively. Like the previous errors, this category of errors may be caused by the learners application of both strategies either overgeneralization or hypercorrection to be as major sources.

\section{1. 7 The use of the indefinite article with adjectives}

The last category in which the indefinite articles are used with adjectives seem to have less importance due to the small numbers of errors which are mostly committed by freshmen with two errors $(1.78 \%)$ of the total number of errors committed by both groups across the mentioned types of errors. No errors made by sophomores in this category which indicates that they are aware of nouns and adjectives and that the definite articles cannot be used with adjectives alone in English sentences. They show much knowledge of the use of the indefiniteness system in this category than freshmen. This error could be made as a result of overgeneralization strategy. That is, at the time in which the learner realizes that an adjective in a sentence sometimes serves as the head noun phrase, thus, he/she may commit errors in using the definite articles with other adjectives by applying the overgeneralization strategy. In other words, the learner in such a case extends this structure to use the indefinite articles with different adjectives. 


\subsubsection{Order of errors}

Based on the results obtained in table 6, the error types can be ordered in terms of the number of errors made by both groups of students in each type. The deletion category was the first category in the order as it has the highest total of numbers of errors (34) representing $(30.35 \%)$ from the total number numbers of errors followed by Substitution of the definite article for the indefinite category with (24) errors representing (21.42\%). the use of indefinite article with unmarked plurals came the third with (14) errors representing (12.5\%) then both categories Substitution of the indefinite article for the definite and the use of the indefinite article with uncountable nouns came together in the fourth stage with (13) errors and with a percentage (11.60\%) for each. In addition, the use of the indefinite article with marked plurals came fifth with (9) errors with a percentage (8.03\%). Both categories: writing "a" as a part of the following word and the use of the indefinite article with adjectives, came sixth with (2) errors representing (1.78\%) for each. Finally, substitution of $\boldsymbol{a}$ for $\boldsymbol{a n}$ came the last in order with a single error representing (.89\%) of the total errors committed.

\section{Conclusion}

This study aimed at identifying the types or errors made by non-English majoring undergraduate students at Omar AlMukhtar University The result obtained from the findings showed that the major sources of errors are the intra-language (i.e. the learners' lack of knowledge about the target language), as well as the common learning processes such as overgeneralization and simplification of the English article system. In addition, the effect of the learners' inter-language system (i.e. native language transfer) was found minimal as because it was found to be responsible for only one type of errors which ids the deletion of the indefinite article. Evidently, the current results suggested that student with weak skills and who lacks competences in English language are more liable to make errors as compare to those who have good skills and competence in English language.

\section{References}

Abdul Haq, F. (1982). An Analysis of Syntactic Errors in the Composition of Jordanian Secondary Students. Unpublished MA Thesis. Jordan. Yarmouk University.

Bataineh, R. F. (2005). Jordanian Undergraduate EFL Students' Errors in the Use of the Indefinite Article. Asian EFL Journal, Volume 7. Issue 1, Article 5, p.p. 1-20.

Bataineh, R.F. (2002). A case study of the impact of the native language of an adult Arab learner of English in an English-speaking environment. Indian Journal of Applied Linguistics, 28(1): 5-26.

Brown, R. (1973). Development of the first language in the human species. American Psychologist, 28, 97-106.

Celce-Murcia, M., \& Larsen-Freeman, D. (1999). The grammar book: An ESL teacher's course. Boston: Heinle and Heinle.

Lyons, C. (1999). Definiteness. Cambridge: Cambridge University Press.

Master, P. (2002). Information structure and English article pedagogy. System, 30, 331-348.

Master, P. (1987). Generic the in Scientific American. English for Specific Purposes, 6(3)165-186.

Master, P. (1997). The English article system: Acquisition, function, and pedagogy. System, 25, 215-232.

Parrish, B. (1987). A new look at methodologies in the study of article acquisition for learners of ESL. Language Learning, 37, 361-383.

Rababah, G. (2003). Communication problems facing Arab learners of English: A personal perspective. TEFL Web Journal, l2(1), 15-30.

Rinnert, C., \& Hansen, M. (1986, October). Teaching the English article system. Paper presented at the Japan Association of Language Teachers' International Conference on Language Teaching and Learning. Tokyo, Japan.

Rinnert, C. and Hansen, M. (1986). Teaching the English article system. Mimeographed (ED 28446).

Thomas, M. (1989). The acquisition of English articles by first- and second-language learners. Applied Psycholinguistics, 10, 335-355.

Wrase, J. (1982, November). Should I write $a$ or the? Paper presented at the Baltimore Area Teachers of English to Speakers of Other Languages (BATESOL) Conference. Baltimore, MD.

Zughoul, M. R. (2002). Interlanguage Syntax of Arabic-Speaking Learners of English: The Noun Phrase. ERIC Document \#: ED479649, pp. 1-23.

Zughoul, M. and Taminian, L. (1984). The linguistic attitude of Arab university students: factorial structure and intervening variables. The International Journal of the Sociology of Language, 50. 